\title{
THE ROLE AND IMPACT OF RELIGION ON THE ARCHITECTURE OF MOSQUES AND CHURCHES
}

\author{
Amineddin Salimi \\ Architecture Faculty of Near East University \\ Aysegul Yurtyapan Salimi \\ Architecture Faculty of Near East University \\ Nuran Kara Pilehvarian \\ Architecture Faculty of Yildiz Teknik University
}

\begin{abstract}
Art has been included customary and possible dimensions to speak by man with holiness, before when was related to the veil of human's egotism. In this age, since the dimension was not sourced from right and truth for man and good names of providence did not come to seek the veil of idolatrous, symbols and motifs appear the occult meanings and themselves are showy of theological facts. The art can appear as religion, because from our sight of principle of knowledgeable, art and religion are intertwined naturally. Every ingenious demonstrate the mysteries that don't appear except with brightness of intellectuality, and it is for having a share of the divine realm, which is the agency cause of manifesting artistic works. The ingenious should attract to the truth to create the making clear beautiful faces by assisting God diffusion. Ingenious lives in the shadow of the verbal knowledge tree. In this sense, if we look closely, we can find very similarities between religious and artistic knowledge: knowledge of art is as immediate and direct as religious knowledge. In the knowledge of art, the reason was not discussed as well acquired knowledge. Therefore, in this study, we investigate the religious influence on architecture, especially on the architecture of religious buildings such as churches and mosques.
\end{abstract}

Keywords: Islamic art, Christian art, Religion, Architecture, Mosque, Church

\section{CAMI VE KILISELERIN MIMARISINE ROLÜ VE DIN ETKISI}

\section{Öz}

Sanat insanın bencilliğin peçe ile ilişkili iken önce, kutsallık ile adam tarafından konuşmak için alışılmış ve olası boyutları dahil edilmiştir. Bu çağda, boyut insan ve ihtiyat iyi isimler için sağ ve gerçeği kaynaklı değildi çünkü putperest peçe aramaya gelmedi, semboller ve motifler gizli anlamları ortaya çıkar ve kendilerini teolojik gerçekler gösterişli bulunmaktadır. bilgili, sanat ve din ilkesi bizim gözden doğal iç içe, çünkü sanat, din olarak görünebilir. Her marifetli zihinsellik parlaklığında dışında görünmüyor sırlarını göstermek ve sanatsal eserlerini tezahür ajansı nedenidir ilahi aleme, bir paya sahip içindir. ustaca Tanrı difüzyon yardımcı olarak yapma açık, güzel yüzler oluşturmak için gerçeğe çekmek gerekir. sözlü bilgi ağacının gölgesinde Dahice yaşıyor. yakından bakarsanız bu anlamda, dini ve sanatsal bilgi arasındaki çok benzerlikler bulabilirsiniz: sanat bilgisi dini bilgi gibi acil ve doğrudan. sanat bilgisi olarak nedeni de elde edilen bilgiyi ele değildi. Bu nedenle, bu çalışmada, özellikle kilise ve cami gibi dini yapıların mimarisine, mimarlık dini etkileri araştırıldı.

Anahtar Kelimeler: İslam sanatı, Hıristiyan sanat, Din, Mimarlı, Cami, Kilise

\section{INTRODUCTION}

Since the beginning of human history, art has always been synonymous with religious subjects and expressions and concepts, which gradually predominance of mundane concepts on the human life, the fields were proportionally branched from it. In fact, just as blasphemy and polytheism prevail over 
divine and monotheistic reflection and worldview, the art was created according to the that reflection and worldview, therefore, art can be created according that reflection and worldview, to the extent that art when to explain spiritual and intellectual truth and stating its beauty, today was changed to the veil of truth [23]. Art and art works surviving from ancient times of human life, indicating a sacred bond (religion) with artistic imagination or experience of mankind. Therefore, religion as a source of spiritual inspirations for creativity and human culture joins the humanity and divinity in the way of custom and myth. And art introduce man's unknown personality to the visible images by visualizing experiences, stories and dreams, and fulfill its decisive role in the evolution of all the world's religions; because performing customs and tradition of myths, religion and art, both in theory and in practice, are united with each other. In the other words, art presents the same goal of religion, which is salvation and exaltation of human, in the form of superior ideally or holy models to humans. When the religious acceptable and reliable goals are explained through images, art convert to a religious medium, and this unique connecting form strengthens the beliefs, traditions and values [3]. Therefore, art when is served for religion and it is influenced by that, makes permanent itself and when was opposite of religion, went to abyss of vanity and decline, as in modern times, we see the serving art is for humble goals and against of prophetic mission of [23]. The main intellectual needs of human were considered in the house of worships, because those were best human's architecture in history, which are built according to the criteria and concepts of creation world. Therefore, exploring the various connecting aspects between art and religion and their influence in religious places of different religions (Islam, Christianity) is investigated [25].

\section{HYPOTHESIS}

In different religions, religion affects on the architecture of religious buildings.

\section{METHODS}

To investigate the influence of religion on the architecture of religious buildings in the different religions (Islam and Christianity), research methods including library, documentary studies, and papers were used.

\section{THEORETICAL PRINCIPLES}

\section{THE DEFINITION OF RELIGION}

Religion that is also called custom and faith; it literally means the way and method, which so it can be interpreted in a way that human choose for his life.

Also, religion in terms is a worldview and a set of beliefs that seeks to offer an explanation for a series of questions that he raised during human life, such as how to create objects, animals, and quality of beginning and end of things, and how to live [10].

\section{THE DEFINITION OF ART AND ITS FEATURES}

Art, one of the most mysterious aspects of human culture and civilization that always pervades the human life. Wherever investigating of history civilization and archaeology discover a sign of civilization and human culture and its manifestation and in every land where a civilization has emerged, works and various manifestations of art were excited admiration of researchers of civilization and art historians and its hidden secrets caused to reflect the philosophers. A scholar of art history represents bright physiognomy from human's civilization and culture in former territories by studying the art works and its manifestations. Art is the mysteries of creation and life of human culture that it calls the reflective of human scientists to further research [2].

- The art is not necessarily creative.

- Art is fully functional.

- It experience to enjoy

- Art is a by-product.

\section{THE DEFINITION OF MOSQUE}


In terminology, mosque refers to a local that is the place of worship and humility front of exalted God. The mosque word is applied for a special private house that was built to worship and another application is according to the narrative of the Prophet (greeting to him), which refers to throughout of land. Because all the earth can be prostrate by Muslim. This is the second application, which is the general applicability of the mosque, is the allocations of the Islamic nation [7].

\section{THE DEFINITION OF THE CHURCH}

The word "church" was sourced from the Greek word [19], which means "congregation" or "community" [27]. This word is used 115 times in the new era. 61 times in Paul's epistles, in the Acts of the Apostles for 23 times, 20 times in the book of Revelation and in the other epistles in new era is used a total of 11 times.

The word church has two common applications. First, it means "Assembly of Christian believers", which is used excessively in the new era, and in fact, assembly of believers is called church. Therefore, the purpose of the church at Corinth, is the Corinthian Christians collection and purpose of the Church of Antioch, is Antioch Christians.

Paul's in the first his epistle and also in an epistle to Corinthians writes: "I oppressed church of god" [18]. In this application, and so on, meaning is the Assembly of Christian believers. But, later, to divulge differences between the Christian church (Assembly of Christians), a new meaning of the word church i. e. "sect" was used, therefore, the meaning of the Catholic Church, is the Catholic sect and the meaning of the Lutheran Church, is the Lutheran sect.

The second use of this word is about a building where Christians worship in it.

\section{ARCHITECTURE AND ITS IMPACT ON ART}

An important aspect which can be seen in our architectural past is the creating the peace and security spirit in the life space of the city and the built monuments. Architects of that time with Harmony factors such as rhythm, repetition, horizontal lines and fit components have made it possible. That is a type of Architecture which was considered to virtually patterns more than all aspects that can be effective in creating a sense of place. Architects who are looking to create a work of art and rich of spiritual concepts and ideas that can also be held accountable in different era. The special understanding of the aesthetics that carry the important indices of art while still is functional. The arched and works in the vestibule of a residential house to entrance porch of mosque are a witness of this. Elegance and precision in the tiled exterior of a mosque as movement relations and how to classify space as are important and offer the poetic and mysterious statement of the architecture. The most important role of art is determination of the possible complexities of phenomena; namely, the new combination of known elements offers to understand more for us and states a correct situation of our unknown life. It reasons that the art participates in human change and reality of inner and outer his world and has the ability to change and reform. The art doesn't describe the reality variously, but it directly states certain aspects of reality and can say that art explain the complexities of phenomena as more clear and understandable for man. Architecture requires the superior realities and worth in association with art. Architecture has a visual statement of ideas, which makes significance the different concepts for human and organizes the reality, a correct definition of human station in the universe that can also cause growth and elevation [24].

\section{THE NATURE AND FORM OF ISLAMIC ART}

Islamic art is different from the art of other cultures both in form and image, constitutive elements and factors and even in the theme and concept. For example, Islamic art in general and focuses mainly on the issue of color unlike the West art which has more interest in the form and image. East art has feminine and feeling characteristics and almost color topic has a certain important in Islamic art, while West art has manly and intellectual characteristics and was created at the basis of plastic and inflect schemes and oblivious to color. Islamic art have been never seen a lack of reasoning and thought even the simplest art designs. The very overt and covert messages can be finding in all forms of Islamic art that invite to view and learn. 
The characteristic of Islamic art is similarity between geometric design and crystal forms. The main difference between Islamic art and art of other cultures is that focuses on the figures and pure images, which is front of natural objects. These images make a variety of shapes and patterns. Islamic art was classified into three categories, illuminated with flowers, geometric shapes and calligraphy art [22].

\section{RELIGIOUS ART (THE ART OF ISLAM AND CHRISTIANITY)}

If the purpose of religion in religious art is absolutely religion, the peak of religious art can be known sculpture when it was worshiped. An art that could replace the deity of certain people in a sculpture and place it front of them, how could not be the greatest religious art of that people. An art can be religious art which establish harmony between nature and temperament; i. e. take go the nature to temperament, the body was made the allegiance of the spirit, make the spirit Imam, the body was followed the spirit, and not contrary that the spirit and temperament be following and body be Imam. Therefore, the work and creatorship were desired for temperament is religious art and someone has such creatorship is religious ingenious [15].

\section{ISLAMIC ART}

It refers to the part of art that current in the Muslim community and not necessarily by Muslims. Although, these arts may be not conformed to Islam instructions and religious law in some cases, but Islamic and regional influence of culture on that is exactly evident.

Islamic art is one of the glorious eras of art history and one of the greatest human achievements in the field of art and contains a variety of art including architecture, calligraphy, and painting. Islamic art is not an art that only related to Islam. The adjective "Islamic" not only refers to the gilt, but also refers to the rich and diverse culture of people in lands where Islam is prevalent it. Furthermore, those concepts and art cases that were existed within Muslim communities in affecting the factors of regional and local culture were said Islamic art [14]. One of the most important appearances of Islamic art is architecture. In particular, mosques with four veranda and columns that is indicators of the art of Islamic architecture. These magnificent mansions can show the impact of different cultures within Islamic civilization. The role of domes in Islamic architecture has been impressive and dome was used has been used in Islamic architecture during the centuries. Remainder oldest dome in Islamic history, is part of the monument Ghobat-el-Sakhreh in the year $691 \mathrm{AD}$. Another indicator domes belongs to the beautiful building Taj Mahal, which is the Iranian-Hindi architecture of the 17th century. In the late nineteenth century, Islamic domes were integrated with Western architecture. Islamic art and especially Islamic architecture are at the basis of the humanity, self-sufficiency, avoiding futility, utilizing introspection, and certainly Iran Muslim ingenious relied on that more than other people [1].

\section{CHRISTIAN ART}

It applied to the art of post-Christianity to pre-Renaissance European. Christianity was initially banned in ancient Rome. Therefore, Christians was drawing their paintings in Katakombs. When Christianity was having a quorum by Constantine in the early 4th century AD, the Byzantine city was renamed to Constantinople. Since this history, Christian art was formalized. Basilica or rectangular churches were built. St. Peter's Basilica was including this church, which was not remained anything [11]. First muralist and then tessellation were developed. Because of opposition of Christian, little statues were made. The peak era of Byzantine art is in the emperor Justinian in the sixth century. In this era, Ravenna was conquered by Eastern Rome and the very important church of San Vitale in this city was built. Emperor Justinian and attendants and Emperor Theodora and attendant's mosaics are the most important Roman mosaics in this church. In this era, the church of Santa Sofia was built in Constantinople [21].

Christian art, both in terms of style and quality, compared with thousands years-old arts of East civilization was amazingly interrupted. For example, while Islamic art after emerging could change the artistic heritage of ancient Greek and Roman world in the areas under its influence, and became founder of the way and the new way in art, Christian art, not only failed for the legacy of their 
predecessors, but some naturalism elements, which had also anti-spiritual property attracted by them [13].

\section{IMPACT OF RELIGION ON ARCHITECTURE}

Influence of religion in the field of architecture has been became the subject of extensive research. Old ritual of worship did not know an indoor place necessary, but on the contrary, Buddhism believed to the keeping the objects and sacred human remains. Therefore, they found to need an indoor place and the building. The custom of worshiping the dead has the amazing impact the Far East: In this area, the nice and small decorative objects were emerged. It means any home is changed to the shrine of ancestors. But in small houses, allocated place for objects and statues of ancestors could not occupy a great place. Therefore, dimensions of ritual objects have made small. Also, in converting ancient art to modern art, we see the adherence to the religious changes; it was made clear the conversion of ancient art to modern art through these changes. The gods of Greece are manifestation of the natural powers, therefore temples are limited but the Christian God is infinite himself and inevitably temples become large [8]. Architecture is a process that directly related to the people beliefs and in general their religion. As we observed that every region and country has its own architecture, we can find that religion plays a major role in architecture. The religion shows its effects on the building more than other factors, so that we see two different houses which is an area with similarity of ground and weather and climate [16]. The one of architectural elements that affected by Islam can be pointed to the mosque; also architectural elements that Christianity can be affected are churches and palaces. These elements rise from the urban texture and it looks that their doors open to all humanity, and with their towers and minarets want to rise in the sky. The religious groups arise in the distinction between the sacred and the profane world. The challenge of the two, the differentiation becomes more apparent [17].

\section{IMPACT OF RELIGION ON THE ARCHITECTURE OF ISLAMIC MOSQUES}

Islam progress in all the aspects of man; in this religion, all things are affected by the sacred order. That means that in life is no difference between the holy and non-holy. Just there is a hierarchy that is rooted in divine unification. This unification is hidden in all things and is very obvious in the art of Islam world that have not any differentia between fine art and applied industries; the technique and aesthetic are complementary aspects of artistic creativity. Islam is neither great to mean the glory of ideals and achievements of a particular civilization, which we see in the Renaissance, and nor the promoting person's mental expression, which we see on the modern art and architecture. This means that a civilization built its monuments to bow upon God, and each of their aspect is remembering its greatness [2]. Islamic traditional town have not any large streets or landscapes. The most important of inhabitants' building at beside of them was elevated as a sign of cultural achievements. Although the sacred architecture of Islam is the architecture of the mosque, however the mosque never been separated from other urban environment. Islam, as noted, does not divide the life of your nation the territory of holy and non-holy. The holy matters progress in the all manifestations of the urban environment and the same ceremonies adduce in the both mosque and home. The mosques in the Muslim world cannot be exactly seen from outside, because the structure of dense urban environment surround them. The experience of this architecture is in its internal architecture; therefore, this architecture emits human from out of the plurality of worlds to the deep thinking and spirit territory of world [9]. 


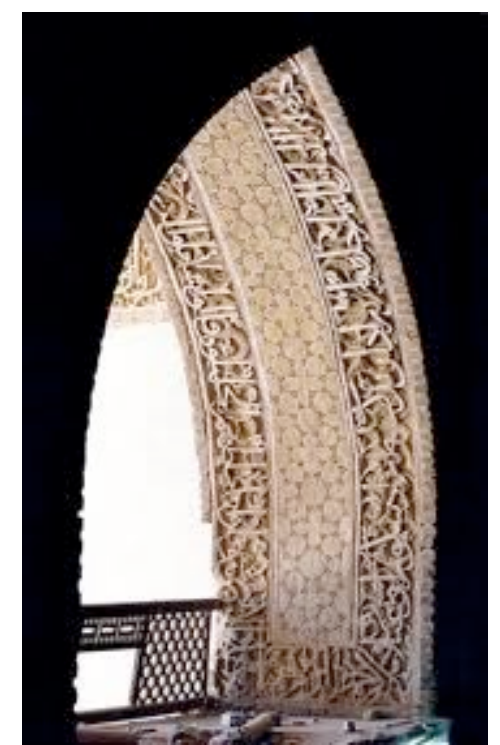

Figure 1. Verse writing on the religious buildings

The architecture is the art of organizing space. An architecture that has a source of holy tradition spread this poetry from material space to explain metaphysical poetry; therefore, the goal of this type of architecture is replacing human in presence of God in the way of making holy of space. To diet the making portraits in art and architecture of mosques, which it ceases to exist the possibility of visualization of the presence of God in the image or portrait, is an important factor in emphasizing the significance of empty spiritual space in the minds of Muslims. Empty space in this way and also due to the principle of unification has converted to a sacred element. In this position, God and his beautiful manifestations will not be considered unique with any place, time or one particular object. His presence is pervasive. It should be noted that is monotheistic thinking of Islamic art. Muslim ingenious passes away from superfluity and arrives to unity. The selecting geometric patterns and the least use of human motifs in mosques emphasize this. Because of manifestation of monotheistic reflection in the architecture of mosques, the architecture of mosque and their decorations in the dome, minarets, epigraphs and internal space creates a space that likes human with the purity of a celestial space. The mosque architects try to show all elements of the building as a manifestation of God's verses. Therefore, the rank of neighborhood to God was showed in the maps of building and bricking and designs on the glazed tiles and plaster-moldings [6]. Muslim architect tries to design mosque which human see his spiritual remembrances as alive and focused to a perpetual world, which is without of limitations of world, and make mystical revelation of lost truth: the world, goods, goodness and beauty, a world that is free from contamination Idols and sex objects, architect uses the images here that the Quran says about heaven and design its optimal space on its foundation [3]. The considering to the order and continuous observation of proportion, it calls him to a pure, specific and correct geometry. In his view, the geometry of the hinge between matter and meaning is earth and sky and uncluttered. Therefore, the figures are in their ultimate purity and perfection. Because of architect look that is not weak and fractured and chaotic looking, therefore we never observe courtyards, floors, rooms, yards, porches, minarets, domes, open spaces, closed spaces and even gardens in the fractured and fragmented and non-geometric shapes in the architectures of mosque [3]. The purpose of proportionality in the mosques is not just the observations of size and applying it, but it means that there is a determined ratio between components, and therefore it was received as acceptable, symbolic and promoting. The proportion that presents often in architecture is a proportion of a pentagon. Of course, other ratios are possible such as ratios of emerging from integers in the valley [3]. Some bright styles exist on the evolution of architecture in Islamic architecture that affect on Islamic architecture. For example, the styles of Arabic, Azeri and Persian which are three main styles of Iranian architecture. There are excellent styles of architecture in the Iranian architecture history, for example these styles were greatly used in architecture styles. Some templates of this architecture are masjid-ijami Fahraj and masjid-i-jami Isfahan, which is the effect of these styles on the architecture of 
buildings and evolution of Islamic architecture and relationship between this style and other how is [32].

\section{FAHRAJ MASJID-I-JAMI}

Fahraj Masjid-i-Jami is one of the oldest mosques, and Represents a simple architecture in the early centuries of Islam. The main materials for the construction of the mosque from the large bricks that had been dried in the sun [29], and Its facade was covered with a mixture of clay, sand and chopped straw. The minaret of mosque was built the small brick raw in the tenth or eleventh century. The eastern wall has been reliefs of Sassanid period. It has a half-open porch on the southern side that it is also called Qibla porch.

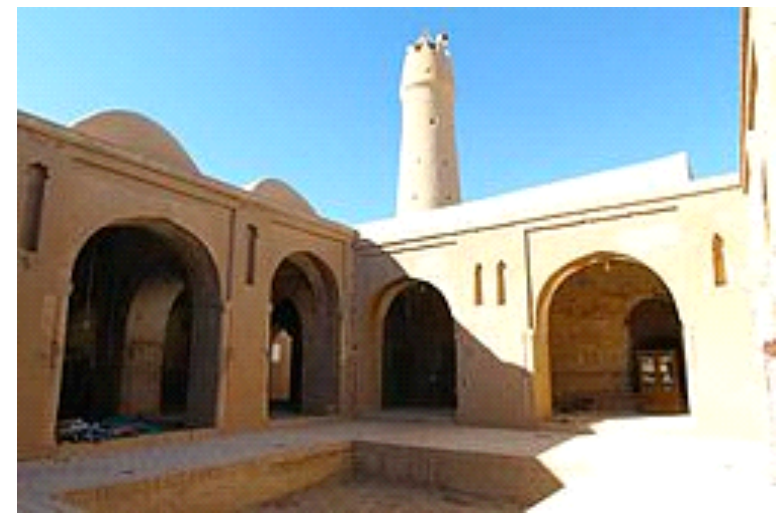

Figure 2. Fahraj mosque and simplicity in its architecture

This style of architecture reflects the deep influence of religion on architecture, so that Islamic monuments such as mosques were built a very simple based on the religious teachings to be very simple and without decorations or at least with the lowest decorations. Therefore, it can be seen as good the impact of religion on the architecture of religious buildings such as Fahraj Masjid-i-Jami in its architectural style.

\section{HISTORY OF MASJID-I-JAMI IN YAZD CITY}

Masjid-i-Jami of Yazd is the largest mosque in the county of Yazd. The mosque was used from the 12th century to the present day, and in during the years 1324 to 1365 has been restored in several periods [32]. Architectural features of Masjid-i-Jami of Yazd are in terms of architecture as one of the best examples of Azeri architecture.

This mosque is decorated by a pair of minarets in the north porch. Incoming facades is decorated with Tiling from top to bottom [32]. The mosque was mostly blue tiles, and this color reflected the Muslim religion's spiritual status to reach tranquility [33].

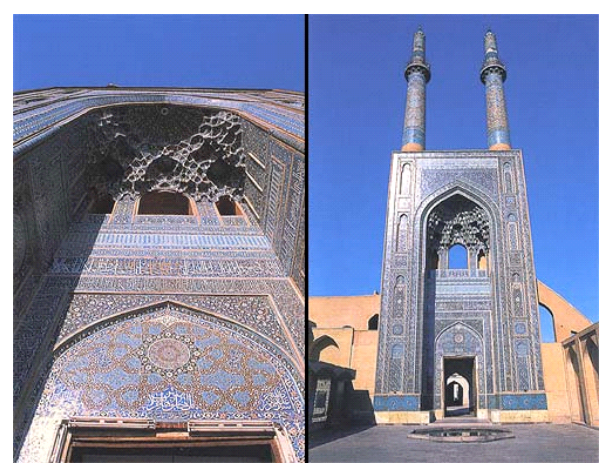

Figure 3. Use the blue tiles to achieve tranquility and spiritual dimension

\section{IMPACT OF RELIGION ON CHURCH ARCHITECTURE OF CHRISTIANITY}

When Christianity became necessary throughout the Roman Empire from Constantine as the official religion and practices of Christian prayer, and so added the importance of Christianity. There were all 
architectural components for its implementation: the open atrium house, the cellar chapel, a Roman basilica, how these elements were elaborately combined with each other, and One of the first Christian church buildings in the new era, that's mean created the old church of San Pietro in Rome [12].In Christian art and architecture encounter with a simple transformation of contents belongs to the Roman religion into the Christian religion and the freest borrowed from pre-Christian issues and practices. Every religion has its own inspiration source, and is established on the basis of ancestral worship or worship of nature symbols, as rely on the Nirvana or the mystery of the Cross. This variation in emanations is reflected in a variety of architectural techniques. Existence of religious groups is caused by the distinction between the sacred and the profane world, which due to these two challenges, the differentiation becomes more apparent, and as a result emanates two kinds of art in society: religious art and secular art. The aesthetic dichotomy is quite with the barbarians and the Kanak in new Caledon that make holiness statue of its own mythical building, and yet on the branches of dried straw, roles of tiny in order to draw visual enjoyment [26]. Ecclesiastical art in architecture of church sideswipe Ta'ziyeh khani, and the epic myth about the religious foundations with secular art such as architecture of palaces, castles. The conflict between these two types of art is continuously exacerbated by the oldest days so far. However, this dichotomy is not prevented the transmission of an art form from one group to another. But its meaning is changed in this transition. For example: Lyrics along with the Franciscan cult movement penetrate into the Catholic Church. Their theme is which love remains, but their meaning and purpose change [26].

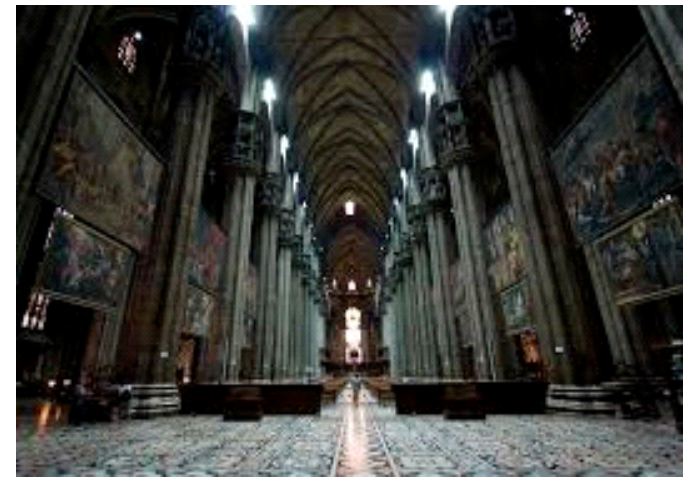

Figure 4. Shows the elongation of the high-rise building in the Gothic churches reach God

Many Christians decorated their churches graffiti in a way late antique-style even in terms of theme, and in the interpretation of the paintings said that they are compatible with their beliefs. Geometric designs painted ceiling of the cryptic tomb of the two Roman Saint who are called San Pietro and San Marchlynv used in Rome means large circle, and inside have been included the Cross that's mean the main symbol of, the Christian Belief. Cross arms end the semicircle that their inside has been described with scenes from the Old Testament book of Jonah's life, which thrown into the sea at the left and on the right side from palate of whale comes out, and be seen healthy on dry land in the bottom part again, which miracle of itself salvation and mercy of God has been thought [30]. Kind of communication during the era of Christianity (A time when religion, particularly, the church dominated societies) is vertically defined. This means that all aspects of life were defined to the Lord and for the Lord. The pattern in Christian era architecture indicates itself as upward arrows [36]. Iranian palace plan reconstructs in Asia Minor and Syria in Christian Church older buildings. Lalo emphasized that art is not religious in its essence, but when a group of men of God use their religion, be religious. Photos and religious objects are not just a simple expression but also contain good or bad magical powers. That's why painters in different periods of the Christian churches has painted them in accordance with established principles to their magical force to remain still dominated by humans [20].

\section{DECORATIONS OF COLOR AND PATTERN IN THE ARCHITECTURE OF MOSQUES}

In the mosques firm mostly motifs and decoration herbal themes and be sometimes mixed with human and animal figures, which in the tendrils motif, leaves and stems is lost. And the meandrous motifs create a pattern that across a surface covered. Relationship between one forms of other in Islamic art is 
more important than the whole motif or plan. Carved decorative Styles in Islamic mosques on wood, tile, stucco is the most common decorations and seen very little masonry. One of the decorating and arrangements in the Islamic architecture of mosques is the art of calligraphy with Arabic texts such as the Koran. The colors in these places are all within the realm of blue and turquoise blue. This color is especially turquoise blue that looks throughout the spaces. For Muslims is a symbol of tranquility, the definition of sky and heavenly and spiritual space. These spaces and colors with lighting can make the observer a sense of power of tranquility, and in the mosques, windows and skylights will not be any artificial colors.

There are certain rules to decorate mosques:

Western-style design or anti-religious decorations should not be used.

Plans should be simple and precious decorations prevented.

Decorating and manuscripts is as possible with names of God or the Qur'an lines (scrips) [5].

\section{THE COLOR AND PATTERN DECORATIONS IN CHURCH ARCHITECTURE}

In the church, more patterns are based on the beliefs of the people. These patterns represent heaven and hell and the life of Christ. Every shape and color in the church is defined as a certain sign for the Christian.

\section{SYMBOL OF THE DOVE OR PIGEON:}

Yellow window that is in the shape of a dove and an allegory of the Holy Spirit and has 12 rays of light illuminated that a sign of the 12 apostles of Jesus, which are indicating the grace of God.

\section{Rose window:}

This window is placed in the western walls of the church and still is a symbol of resurrection. The center light is the symbol of Christ that is placed at the focus and other lights are the symbol of messengers, apostles, evangelists, and the angels. It should be noted that this type of pattern (the rose window) has been more common in the Gothic era.

\section{COLORS IN THE CHURCH:}

In this space, hot and spicy colors (red, yellow, and black) are excessively used and we can rarely see the colors as turquoise blue or light blue [26].

\section{CONCLUSION}

According to the mentioned subjects at the before sections can conclude that there is a closed relation between religion and art, and since architecture is a branch of art, it can see very effects of religion on the architecture of buildings, including that the impact of religion on the lives of people in various religions, particularly in the heavenly religions such as Islam and Christianity. Therefore, it is notable that religion affects significantly in design and architecture of religious buildings such as mosques and churches. The church spaces and decorations show the influence of religion on these buildings. It is including the paintings which have been drawn on the roof of churches, and some plans of churches that derived from the cross. Sharp upward windows and broad ceilings are all indicating of the desire of the human's spirit towards God. In the mosque can be also seen these results, the using blue spaces is indicating tranquility, writing verses on minarets, domes and walls, simply and without decorating the mosques spaces, all arising from the impact and the role of Islam, which ordered to be simple and law-decorations. And such architecture show that religion have an appropriate effect on the art, exalted spirit of human and architecture of religious buildings, and man find spirit peace in these places. And therefore, architects present perfection of religion in their works and has attracted the viewer's mind to the perfection of the God, and give ideality spirit to their work, because the work when has perfection and beauty that could clear attributes of God.

\section{REFERENCES}


Arian, H. 2011. The reviewing on the history of Islamic art (in Persian).

Awani, G. 1997. The wisdom and spiritual art, Tehran, Gross (in Persian).

Burckhardt, T. 1992. The eternal values of Islamic Art, Translator: Avini, M., Proceedings of

Burckhardt, T. 2000. Islamic art, language and speech, Translator: Rajbnia Tehran, Soroush (in Persian).

Pourjafar, M.R. 2010. Shahid Sharifi's church architecture, Tehran, Simaye Danesh (in Persian).

Pirnia, M. K. 2009. Methodology of Islamic architecture. Soroush. (in Persian).

Jafarian, R. 2011. Islamic monuments of Mecca and Medina, Page 199 (in Persian).

Dehghan, F. 2011. The architecture of religious places, Tehran, publication of architectural thinking. (in Persian).

Davari, R. 2011. A collection concepts of tradition, modernisation and development. Nameheye Farhang (in Persian).

Durkheim, E. 2005. The basic forms of religious life, translator: Parham, B., Nashre Markaz (in Persian).

Zekrgoo A.H. et al. 2004. Revolution of art in the history, School Publishing (in Persian).

Sojoodi, F. 2010. Jensen art history, Farhangsaraye Mirdashti (in Persian).

Stari, J. 2002. National and cultural identity, Tehran. Centre (in Persian).

Sharif, M. M. 2004 Islamic arts, University Publication Center (in Persian).

Fahimifar, A. 1998. East love, recognition of religious art in ancient history, Kadir publication (in Persian).

Fahimifar, A. 2010, A discussing on the aesthetics of Islamic art, The research in culture and art (in Persian).

Lak, M. 2015. Manifestation of Islamic wisdom and art in architecture of mosques. (in Persian).

Miller, W. 2004. The history of old church in the Roman and Persia Empire. Translator: Nokhostin A., Mythology Publishing, (in Persian).

McGrath, A. 2007. An Introduction to Christian Theology, translator: Dibaj I., Light Book, (in Persian).

Madadpur, M. 2003. Spiritual wisdom and realm of art. Tehran, Islamic Development Organization. (in Persian).

Marzban, P. 2005. The summary of the art history. scientific and cultural publications. (in Persian).

Najib oglu, G. 2001. Geometry and decoration in Islamic Architecture, translator: Ghaiyoomi Bidhendi, M. Tehran, Rozaneh publishing. (in Persian).

Naghizadeh, M. 2001. And interaction of art and economy in the traditional and modern communities, religious art magazine. (in Persian).

Norberg, K. 2000. Architecture: Virtually and placement. Translator: Norouz Borazjani V. (in Persian).

Nasr, S. H. 2007. Islamic art and spirituality, translator: Ghasemian, R. Published by the Office of Religious Studies Arts, (in Persian).

Houyan, A. 2005. Christian churches in Iran, Tehran, Cultural Heritage Organization of the Ministry of Housing and Urban planning (in Persian).

Achtemeier, P. J. 1996. Harpercollins Bible Dictionary, Harper San Francisco

Abu'l Feda, Taqwim al-Boldan. 1840. Slane, Paris

Eșțaknri, M. 1961. Mamalek. Afshar, Tehran.

Kenneth, C. 1924. Early Medieral church Architecture (Baltimor: johns Hopkins press).

Ouria, M. 2015. Introduction in Architectural History of Azerbaijan, under publishing book, TabriIran.

Salimi, A. 2015. An Overview on Islamic Architecture, Case Study; Iranian Mosques

Warren, J. 1991. Creswell's Use of the Theory of Dating by the Acuteness of the Pointed Arches in Early Muslim Architecture 